Jurnal Riset Manajemen Sains Indonesia (JRMSI) | Vol 9, No. 2, 2018

e-ISSN: 2301-8313

http://doi.org/10.21009/JRMSI

DOI: doi.org/10.21009/JRMSI.009.2.06

\title{
EFEKTIVITAS PELATIHAN PRODUK MAKANAN DALAM MENINGKATKAN PENDAPATAN
}

\author{
Nani Dewi Sunengsih \\ Universitas Darma Persada \\ Ardi Winata \\ Universitas Darma Persada \\ Widiastuti \\ Universitas Darma Persada
}

\begin{abstract}
ABSTRAK
Penelitian ini bertujuan untuk menentukan apakah pelatihan dalam mengelola produk bercabang cabai dapat meningkatkan peran ibu rumah tangga dalam meningkatkan pendapatan keluarga. R \& D telah dipilih melibatkan 80 ibu rumah tangga di desa Tangsi Jaya - kecamatan Gunung Halu sebagai sampel yang dipilih secara acak. Ada dua kelompok yang telah ditentukan, satu kelompok adalah sekelompok ibu rumah tangga yang telah mengikuti pelatihan dan kelompok ibu rumah tangga lainnya sebagai kelompok kontrol. Penghasilan ibu rumah tangga telah diuji dengan mengembangkan tes benar-salah (30 item dan hanya 28 item yang valid dengan keandalan 0,92). Data telah dianalisis dengan menerapkan statistik deskriptif dan t-tes untuk memverifikasi perbedaan dan keefektifan produk. Hasilnya menunjukkan bahwa ada peningkatan yang efektif dan signifikan dalam pendapatan rumah ibu setelah mereka menghadiri pelatihan. Jadi di masa depan, meskipun status mereka sebagai ibu rumah tangga, mereka memiliki minat serius untuk berpartisipasi dalam pelatihan. Ini adalah salah satu cara untuk mengubah peran ibu rumah tangga dan mengharapkan perubahan dalam sikap mereka terhadap pelatihan. Pada akhirnya, mereka akan lebih positif dalam meningkatkan penghasilan mereka.
\end{abstract}

Kata kunci: peran, pelatihan, pengelolaan, makanan, olahan 


\section{PENDAHULUAN}

Pembangunan nasional pada dasarnya tidak lepas dari peran kawasan pedesaan. Kemandirian pembangunan kawasan pedesaan menjadi salah satu pendekatan untuk mendorong perkembangan ekonomi di kawasan desa dengan memanfaatkan potensi yang ada di wilayah tersebut. Pada akhirnya, perkembangan ekonomi kawasan pedesaan dapat mengurangi ketergantungan kawasan pedesaan terhadap perkotaan. Peran desa menjadi semakin kuat sebagai pusat produksi dan kebutuhan sumber daya pembangunan. Selain peningkatan pembangunan masyarakat di desa, interaksi ini juga berdampak positif dalam mengurangi angka urban masyarakat desa ke kota. Pola ini diharapkan akan mendorong perkembangan ekonomi desa dan pemerataan ekonomi antara pedesaan dan perkotaan. Dalam skala yang lebih intensif, interaksi antara desa dan kota tersebut dapat berupa interaksi spasial antarsubsistem rantai agribisnis/agroindustri.

Permasalahan utama masyarakat pedesaan adalah rendahnya tingkat pendapatan. Masalah pendapatan masyarakat ini tidak hanya dilihat dari jumlahnya saja, tetapi juga bagaimana distribusi pendapatan yang diterima oleh masyarakat. Masalah pendapatan masyarakat ini berdampak pada berbagai masalah lain, di antaranya adalah tingginya angka anak putus sekolah. Anak-anak di pedesaan tumbuh tanpa pendidikan yang cukup berakibat pada rendahnya daya saing sumber daya manusia (SDM) yang sangat dibutuhkan bagi pembangunan desanya. Masalah kurangnya kesadaran akan pentingnya pendidikan di kalangan masyarakat desa tidak dapat dianggap sebagai hal yang sepele, karena hal itu secara tidak langsung dapat menghambat perkembangan dan kemajuan desa. Rendahnya tingkat pendidikan di desa sebenarnya tidak hanya disebabkan oleh faktor internal dari masyarakat desa itu sendiri melainkan juga merupakan bentuk kurangnya dukungan dari pemerintah. Hal ini terlihat dari ketidaklayakan sarana dan prasarana pendidikan yang ada di daerah pedesaan, seperti terjadi pada masyarakat desa Tangsi Jaya kecamatan Gunung Halu di Kabupaten Bandung Barat.

Pelatihan-pelatihan yang selama ini dilakukan terhadap masyarakat belum dapat meningkatkan motivasi masyarakat desa Tangsi Jaya dalam meningkatkan pendapatan 
keluarga. Perlu diketahui bahwa sebagian masyarakat desa Tangsi Jaya adalah petani kopi dan cabai. Kegiatan bertani kopi dan cabai belum dapat meningkatkan pendapatan masyarakat. Masyarakat desa Tangsi Jaya terutama ibu-ibu rumah tangga seolah kurang termotivasi dalam membantu meningkatkan pendapatan keluarga. Oleh karena itu, masyarakat Tangsi Jaya terutama ibu-ibu rumah tangga perlu dijembatani dengan membantu mereka memperoleh pengetahuan, keterampilan yang memadai tentang pengelolaan usaha, serta pengetahuan dan keterampilan-keterampilan teknis untuk memanfaatkan potensi yang mereka miliki. Dalam hal ini ibu-ibu rumah tangga memerlukan pelatihan untuk meningkatkan kompetensi mereka, yakni penekanan pada penguasaan pengetahuan dan keterampilan fungsional dalam mengelola misalnya tanaman cabai dalam rangka meningkatkan motivasi mereka dalam meningkatkan pendapatan keluarga.

\section{TELAAH PUSTAKA}

Gilarso (2002: 63) berpendapat bahwa pendapatan keluarga adalah segala bentuk balas karya yang diperoleh sebagai imbalan atau balas jasa atas sumbangan seseorang terhadap proses produksi. Menurut Lipsey et al. (2003: 70) pendapatan dapat diklasifikasikan sebagai berikut: (1) Pendapatan pribadi. Pendapatan yang dihasilkan oleh atau dibayarkan kepada perorangan sebelum dikurangi dengan pajak penghasilan perorangan. Sebagian dari pendapatan perorangan dibayarkan untuk pajak, sebagian ditabung oleh rumah tangga yaitu: pendapatan perorangan dikurangi dengan pajak penghasilan. (2) Pendapatan disposibel. Jumlah pendapatan saat ini yang dapat dibelanjakan atau ditabung oleh rumah tangga yaitu: pendapatan perorangan dikurangi dengan pajak penghasilan. Sukmayani, dkk. (2008: 117) ada 5 (lima) factor yang berpengaruh terhadap pendapatan, yaitu: (1) Kesempatan kerja yang tersedia. (2) Kecakapan dan keahlian. (3) Motivasi. (4) Keuletan kerja. (5) Banyak sedikitnya modal yang digunakan.

Pelatihan merupakan salah satu cara untuk meningkatkan kemampuan tertentu. Sebagaimana dinyatakan oleh Mathis dan Jackson (2002: 5), bahwa pelatihan adalah suatu proses dimana orang-orang mencapai kemampuan tertentu untuk membantu mencapai tujuan organisasi oleh karena itu, proses ini terikat dengan berbagai tujuan organisasi, 
pelatihan dapat dipandang secara sempit ataupun luas. Demikian pula, Sulistiyani dan Rosidah (2003: 175) menyatakan bahwa pelatihan adalah proses pendidikan jangka pendek dengan menggunakan prosedur sistematik pengubahan perilaku para anggota organisasi dalam satu arah guna meningkatkan tujuan-tujuan organisasional. Menurut Hasibuan (2005: 68-70) dalam pelatihan beberapa teknik akan menjadikan prinsip belajar tertentu menjadi lebih efektif, diantaranya adalah pelatihan partisipatif.

Pemilihan pelatihan partisipatif pengelolaan tanaman cabai ini beralasan. Ibu-ibu rumah tangga di desa Tangsi Jaya sudah terbiasa bertani cabai, namun hal ini tidak menjadikan mereka termotivasi untuk meningkatkan pendapatan keluarga. Saat ini metode pelatihan partisipatif terus berkembang dan sering digunakan oleh Lembaga Swadaya Masyarakat (LSM) untuk merancang, menjalankan, mengawasi, dan mengevaluasi programnya (http://humancapitaljournal.com/pla-metode-pelatihan-partisipatif ). Prinsip dasar dari metode ini adalah menggunakan pendekatan partisipasi penuh seluruh audiens. Dalam PLA, seorang pelatih lebih berfungsi sebagai fasilitator dan pengetahuan datang dari partisipan. Menurut Suprijanto (2005:165), dalam pelatihan partisipatif digunakan siklus belajar dari pengalaman (experiential learning cycle). Metode ini mempunyai tahapan tertentu, yaitu (1) mengalami, (2) mengungkapkan, (3) menganalisis, (4) generalisasi, dan (5) menerapkan.

Produk tanaman cabai yang dihasilkan ibu-ibu rumah tangga di desa Tangsi Jaya belum dapat mendongkrak pendapatan keluarga. Selain itu, tanaman cabai merupakan salah satu sayuran buah yang memiliki peluang bisnis yang baik. Besarnya kebutuhan dalam negeri maupun luar negeri menjadikan cabai sebagai komoditas menjanjikan. Permintaan cabai yang tinggi untuk kebutuhan bumbu masakan, industri makanan, dan obat-obatan merupakan potensi untuk meraup keuntungan. Tidak heran jika cabai merupakan komoditas hortikultura yang mengalami fluktuasi harga paling tinggi di Indonesia. Konsumsi cabai terus meningkat seiring dengan peningkatan jumlah penduduk dan perkembangan industri yang membutuhkan bahan baku cabai. Produksi dari perkebunan cabai ini direncanakan dipasarkan ke pasar domestik dan ekspor. Untuk pasar domestik direncanakan sebesar 60\%, $70 \%$, dan $80 \%$ dari kapasitas produksi yang pemasarannya dilakukan melalui distributor 
menggunakan angkutan darat, sedangkan pasar ekspor melalui laut dan udara (Samadi, 2007).

Pengelolaan produk olahan cabai meliputi kegiatan-kegiatan sebagai berikut: (1) Pemilihan Bahan Baku, pemilihan bahan baku dilakukan untuk memilih cabai merah yang baik, yaitu tingkat kemasakannya di atas 60\%, sehat dan fisiknya mulus (tidak cacat). Tangkai cabai dan bagian yang rusak harus dibuang. (2) Proses Pengolahan, cabai merah dapat menghasilkan berbagai macam produk olahan untuk menunjang bahan makanan lain diantaranya: (a) Bubuk cabai. Banyak dimanfaatkan sebagai bahan baku industri macaroni, bihun, mie, kecap, kerupuk, emping, bumbu masak, pati, dan industri pelumatan buahbuahan serta sayuran; (b) Manisan cabai; (c) Saos cabai; (d) Pasta cabaian; dan (5) Abon cabai.

Berdasarkan latar belakang masalah di atas, pertanyaan penelitian (research questions) dapat diperinci sebagai berikut.

1. Bagaimanakah prosedur pengembangan model pelatihan partisipatif pengelolaan produk olahan cabai untuk meningkatkan pendapatan ibu-ibu rumah tangga?

2. Bagaimanakah cara menerapkan model pelatihan partisipatif pengelolaan produk olahan cabai untuk meningkatkan pendapatan ibu-ibu rumah tangga?

3. Bagaimanakah keefektifan model pelatihan partisipatif pengelolaan produk olahan cabai untuk meningkatkan pendapatan ibu-ibu rumah tangga?

\section{METODE PENELITIAN}

Penelitian ini adalah R \& D yang didasarkan pada Borg dan Gall (2003). Studi ini diikuti pengembangan model uji efektivitas pelatihan partisipatif melalui metode treatmental, dengan desain pre - post class control. Ada sekitar $80 \mathrm{ibu}$ rumah tangga yang dipilih sebagai sampel secara simple random sampling. Alat untuk mengukur pelatihan partisipatif pengelolaan produk olahan cabai telah dikembangkan dengan menerapkan tes benar-salah (30 item dan berlaku 28 item dengan reliabilitas 0,92).

Ada dua kelompok, satu kelompok perlakuan (treatment) yang terdiri dari sekelompok ibu rumah tangga yang harus mengikuti pelatihan partisipatif dan kelompok lain ibu rumah tangga yang tidak mengikuti pelatihan partisipatif sebagai kelompok control (control). Data telah dianalisis dengan menerapkan statistik deskriptif dan t-test untuk memverifikasi 
Jurnal Riset Manajemen Sains Indonesia (JRMSI) | Vol 9, No. 2, 2018

e-ISSN: 2301-8313

http://doi.org/10.21009/JRMSI

perbedaan dan efektivitas produk. Penerapan model pelatihan patisipatif untuk meningkatkan pengetahuan ibu rumah tangga tentang pengelolaan produk olahan cabai di desa Tangsi Jaya kecamatan Gunung Halu - Bandung Barat dapat dilihat dalam bentuk aliran dalam gambar sebagai berikut.

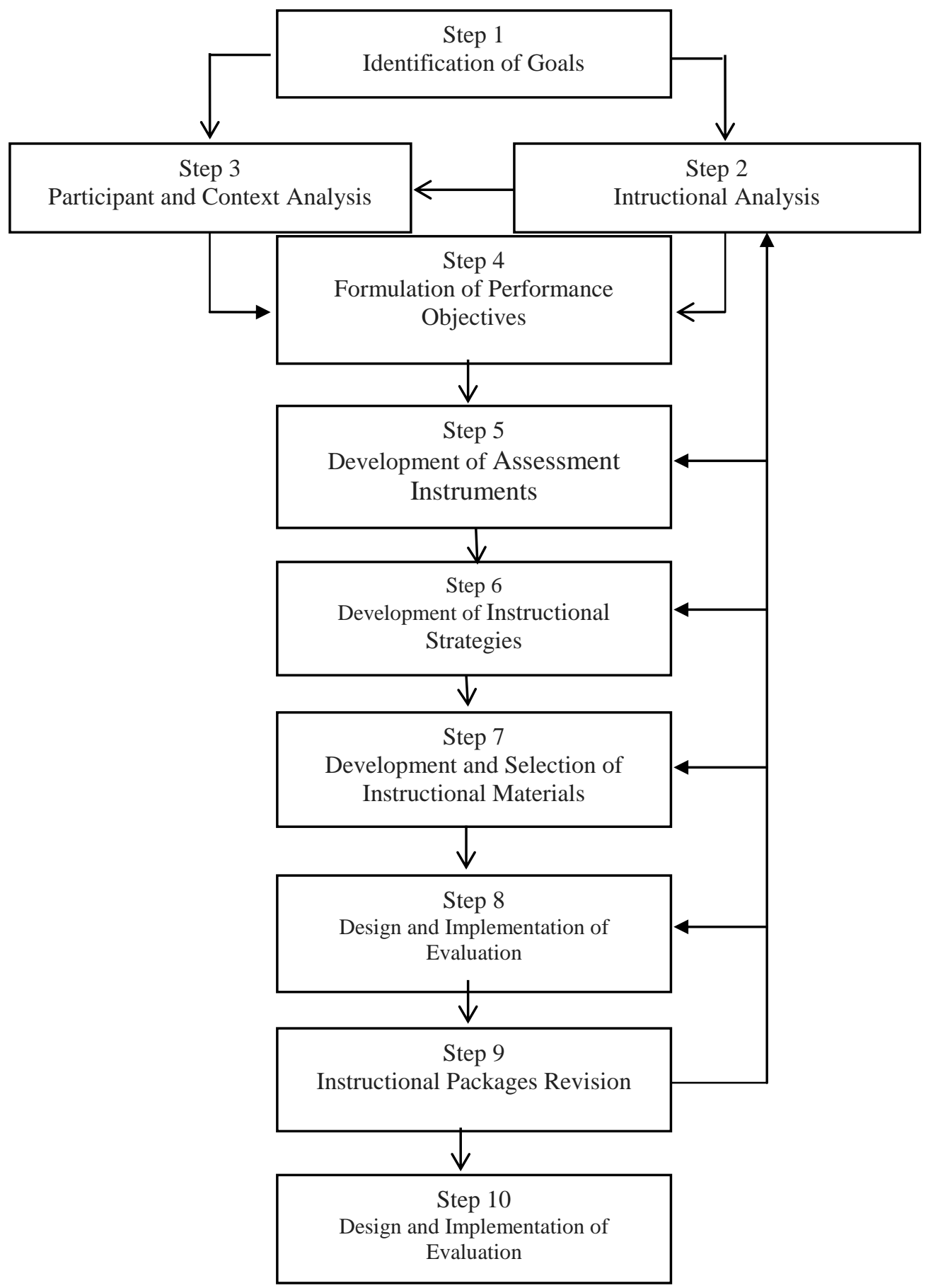


Jurnal Riset Manajemen Sains Indonesia (JRMSI) | Vol 9, No. 2, 2018

e-ISSN: 2301-8313

http://doi.org/10.21009/JRMSI

Gambar 1. Langkah-langkah Pelatihan Partisipatif

Penelitian ini dilakukan untuk menentukan efektivitas pelatihan partisipatif pengelolaan sampah menggunakan metode desain treatmental sebelum tes - setelah tes kelompok kontrol. Desain dari treatmental ini adalah sebagai berikut.

\begin{tabular}{ccc}
$\mathrm{O}$ & $\mathrm{X}$ & $\mathrm{O}$ \\
\hline $\mathrm{O}$ & $\mathrm{C}$ & $\mathrm{O}$
\end{tabular}

Keterangan:

$\mathrm{X}=$ kelas perlakukan (treatment), mengikuti pelatihan partisipatif

$\mathrm{C}=$ kelas control (control), tidak mengikuti pelatihan partisipatif

$\mathrm{O}=$ Pengamatan

\section{HASIL DAN PEMBAHASAN}

1. Pengumpulan Informasi dan Perencanaan (Information Collecting and Planning)

Pelatihan partisipatif pengelolaan produk olahan cabai belum pernah dilakukan. Kerangka pengembangan pelatihan partisipatif pengelolaan produk olahan cabai, yang disusun diharapkan mampu menggambarkan sebuah sintaksis dari paket pelatihan. Berdasarkan hasil studi pendahuluan tersebut, maka langkah awal dalam pengembangan pelatihan partisipatif dalam penelitian ini adalah merumuskan tujuan yang berkaitan dengan pengelolaan produk olahan cabai. Tujuan yang ingin dicapai dari pelatihan partisipatif pengelolaan produk olahan cabai untuk meningkatkan pengetahuan masyarakat tentang pengelolaan produk olahan cabai, adalah sebagai berikut.

a. Ibu-ibu rumah tangga mengetahui pengertian dan jenis produk olahan cabai.

b. Ibu-ibu rumah tangga memiliki pengetahuan tentang proses membuat produk olahan cabai rumah tangga.

c. Ibu-ibu rumah tangga memiliki pengetahuan pengelolaan produk olahan cabai.

Berdasarkan hasil analisis materi mengenai pengelolaan produk olahan cabai yang akan dikembangkan, maka dirumuskan menjadi 4 (empat) topik bahasan, yaitu: Pelatihan Partisipatif 1, Pelatihan Partisipatif 2, Pelatihan Partisipatif 3, dan Pelatihan 
Partisipatif 4. Gambaran alur analisis materi secara skematis dapat dilihat pada gambar di bawah ini.

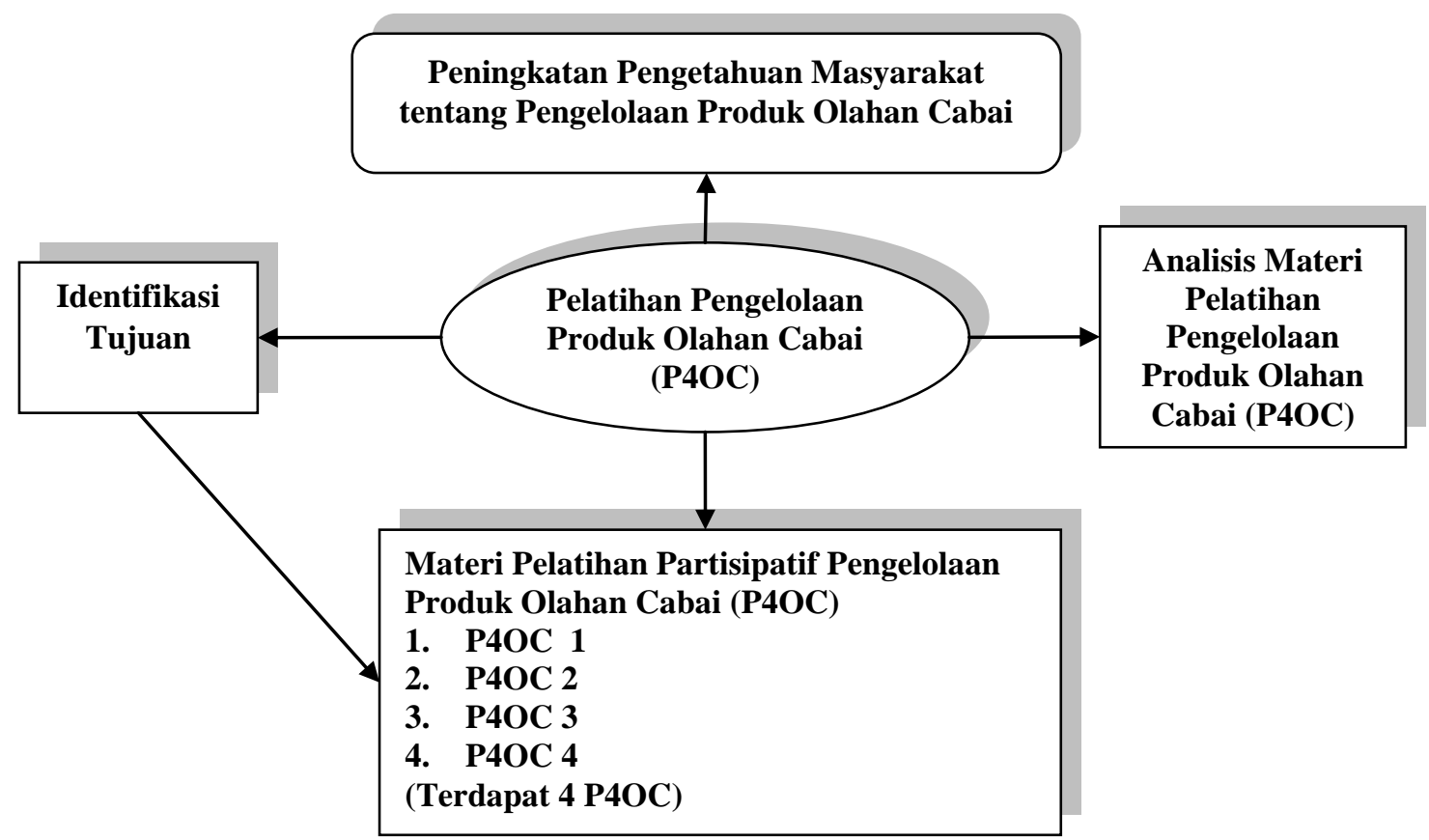

Gambar 2. Materi Pelatihan Partisipatif Pengelolaan Produk Olahan Cabai

Hasil analisis materi yang telah dilakukan kemudian dijadikan dasar untuk mengembangkan materi Pelatihan Partisipatif pengelolaan produk olahan cabai. Pengembangan materi diawali dengan merumuskan Kompetensi Inti, Kompetensi Dasar dan Indikator, yang kemudian dijabarkan menjadi beberapa kompetensi dasar dan indikator pencapaian hasil belajar ibu-ibu rumah tangga.

2. Desain dan Pengembangan Produk (Design and Development of Product)

Langkah selanjutnya adalah mengembangkan materi pelatihan partisipatif sehingga dihasilkan draf paket pembelajaran. Pengembangan materi didukung oleh beberapa buku-buku sumber yang relevan sebagai bahan rujukan untuk menjelaskan konsep-konsep penting yang berkaitan dengan pengelolaan produk olahan cabai. Sedangkan fenomena lingkungan yang banyak ditemukan di sekitar lingkungan ibu-ibu rumah tangga dijadikan sebagai sumber belajar agar lebih mudah dalam meningkatkan 
kegiatan ibu-ibu rumah tangga tentang pengelolaan produk olahan cabai rumah tangga dalam memahami konsep yang diberikan. Prinsip-prinsip penyusunan materi merujuk pada desain pelatihan partisipatif yang dirancang untuk kepentingan penelitian.

Desain pengembangan pelatihan partisipatif pengelolaan produk olahan cabai mengacu pada tujuan kewirausahaan yang menekankan proses untuk mengenali nilainilai dan menjelaskan konsep-konsep dalam rangka mengembangkan keterampilan, sikap yang diperlukan untuk meningkatkan endapatan keluarga. Dengan demikian, kewirausahaan yang terintegrasi dengan pelatihan partisipatif pengelolaan produk olahan cabai bertujuan meningkatkan kegiatan ibu-ibu rumah tangga dalam pengelolaan produk olahan cabai rumah tangga.

Kegiatan ibu-ibu rumah tangga dalam pengelolaan produk olahan cabai rumah tangga secara komprehensif harus didukung oleh pengetahuan tentang pengelolaan produk olahan cabai. Sistem pengelolaan produk olahan cabai antara aspek teknis operasional, pembiayaan dan peran serta masyarakat saling terkait, tidak dapat berdiri sendiri. Desain pengembangan pelatihan partisipatif tersebut digambarkan dalam bagan di bawah ini.

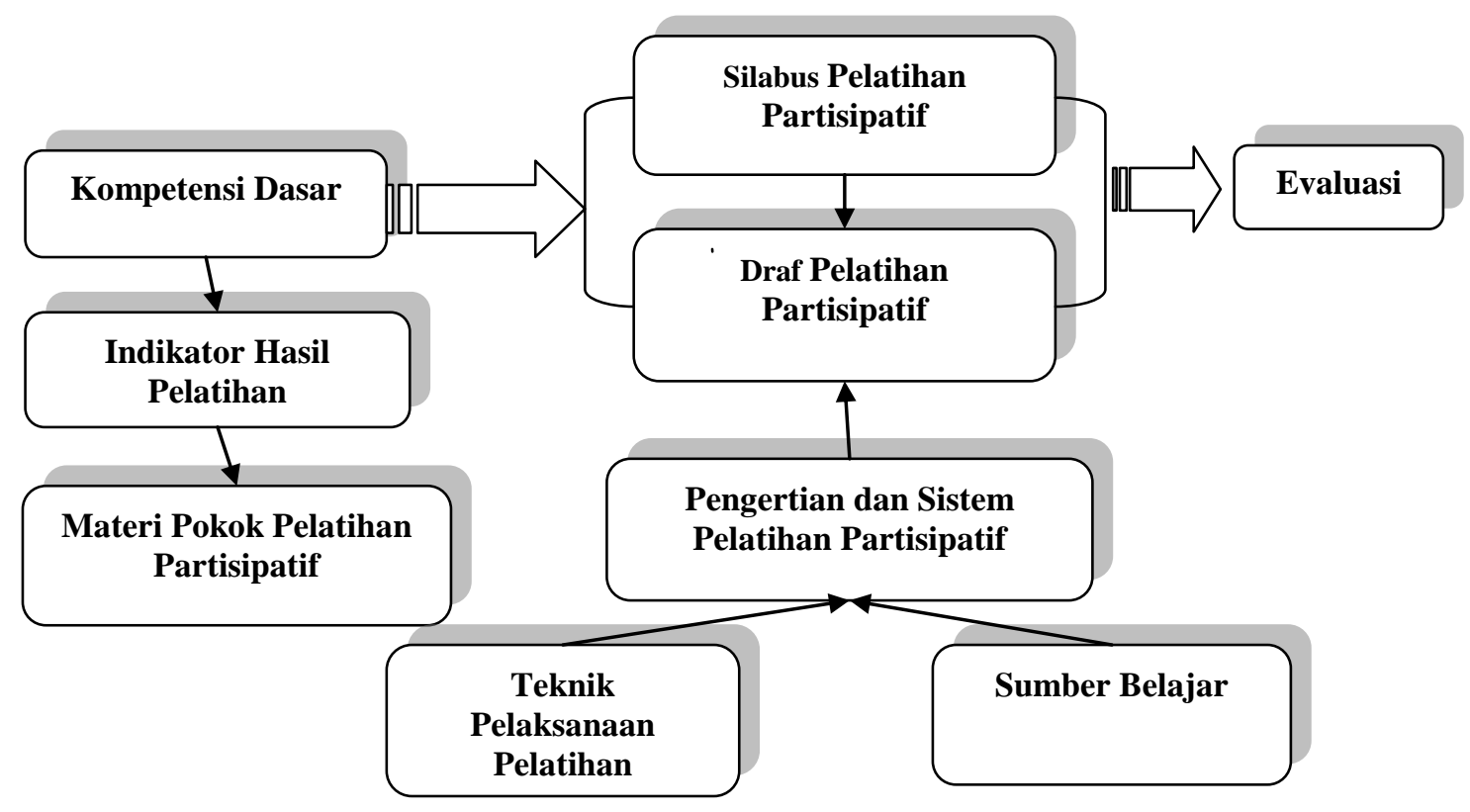

Gambar 3 Desain Pengembangan Model Pelatihan Partisipatif Pengelolaan Produk Olahan Cabai 
Merujuk pengertian dan sistem pengelolaan produk olahan cabai yang akan dikembangkan, maka disusunlah silabus mengenai pengelolaan produk olahan cabai. Pada tahap penyusunan silabus dan pengembangan materi pelatihan, maka karakteristik ibu-ibu rumah tangga sebagai pengguna produk yang dihasilkan menjadi pertimbangan yang sangat penting. Pengembangan materi pelatihan partisipatif pengelolaan produk olahan cabai disesuaikan dengan karakteristik ibu-ibu rumah tangga setempat, sedangkan masalah yang disajikan diangkat dari fenomena kebutuhan masyarakat yang dekat dan dikenal ibu-ibu rumah tangga. Fenomena kebutuhan masyarakat dijadikan sebagai sumber belajar dalam mengembangkan materi pelatihan partisipatif pengelolaan produk olahan cabai.

Desain pengembangan pelatihan partisipatif menggambarkan bahwa pengelolaan produk olahan cabai sebagai sumber belajar merupakan penjabaran dari pendekatan kontekstual yang menjelaskan keterkaitan antara pengetahuan yang dimilikinya dengan fakta yang terdapat dalam kehidupan sehari-hari. Sedangkan kondisi sosial budaya masyarakat sebagai landaan acuan untuk mengembangkan materi pelatihan partisipatif yang berlandaskan pada kearifan lokal. Dengan demikian pelatihan partisipatif yang dihasilkan akan memberikan kesempatan kepada ibu-ibu rumah tangga setempat untuk mengkonstruksi pengetahuannya berdasarkan fakta dan informasi yang didapat, sehingga materi yang dipelajari tersebut menjadi lebih bermakna.

3. Efektivitas Pelatihan Partisipatif Pengelolaan Produk Olahan Cabai

Pengujian efektivitas bahan ajar dilakukan dengan metode eksperimen. Pelaksanaan uji efektivitas dilakukan pada ibu-ibu rumah tangga di Desa Tangsi Jaya Kecamatan Gunung Halu - Bandung Barat, yang masing-masing dibagi menjadi kelompok treatment dan kelompok control. Kelompok treatment adalah pada ibu-ibu rumah tangga di Desa Tangsi Jaya Kecamatan Gunung Halu - Bandung Barat yang mengikuti Pelatihan Partisipatif tentang pengelolaan produk olahan cabai, dan kelompok control adalah kelompok ibu-ibu rumah tangga di Desa Tangsi Jaya Kecamatan Gunung Halu - Bandung Barat yang tidak mengikuti Pelatihan Partisipatif 
tentang pengelolaan produk olahan cabai rumah tangga. Setiap kelompok diberikan tes awal (pre test) untuk mengetahui pengetahuan awal ibu-ibu rumah tangga, dan kegiatan selanjutnya masing-masing kelompok diberikan waktu untuk mempelajari materi Pelatihan Partisipatif tentang pengelolaan produk olahan cabai selama 6 minggu. Pada akhir kegiatan maka kedua kelompok diberikan tes akhir (post test) untuk mengetahui peningkatan pengetahuan tentang pengelolaan produk olahan cabai.

Berdasarkan hasil uji efektivitas menunjukkan bahwa post test dan gain score pada kelompok ibu-ibu rumah tangga yang belajar mengikuti Pelatihan Partisipatif pengetahuan tentang pengelolaan produk olahan cabai lebih tinggi dibandingkan dengan kelompok ibu-ibu rumah tangga yang tidak mengikuti Pelatihan Partisipatif tentang pengelolaan produk olahan cabai. Untuk melihat perbedaan antara kedua kelompok tersebut maka dilakukan analisis statistik, seperti diuraikan pada bahasan berikut. Secara rinci hasil uji efektivitas dapat dilihat pada tabel berikut.

Tabel 1 Deskripsi Data Skor Pre Test dan Post Test Dari Kelompok Control dan Treatment Pada Uji Efektivitas Pelatihan Partisipatif Pengelolaan Produk Olahan Cabai Pelatihan Pengelolaan Produk Kelompok

\begin{tabular}{cccc} 
& & Control & Treatment \\
\hline \multirow{2}{*}{ Skor Cabai } & $\mathrm{N}$ & 40 & 40 \\
& Jumlah & 864 & 732 \\
& Rerata & 21,60 & 18,30 \\
& Modus & 22 & 20 \\
& Median & 22,00 & 19,00 \\
& Rentangan skor & $14-29$ & $10-25$ \\
& St.Deviasi & 3,159 & 2,742 \\
& Varians & 16,295 & 13,003 \\
& N & 40 & 40 \\
Skor Post test & Jumlah & 1122 & 1226 \\
& Rerata & 28,05 & 30,65 \\
& Modus & 29 & 34 \\
& Median & 29,00 & 34,00
\end{tabular}


Jurnal Riset Manajemen Sains Indonesia (JRMSI) | Vol 9, No. 2, 2018

e-ISSN: 2301-8313 http://doi.org/10.21009/JRMSI

\begin{tabular}{ccc}
\hline Jumlah & 218 & 495 \\
Rerata & 5,45 & 12,38 \\
Modus & 5 & 14 \\
Median & 5,00 & 13,00 \\
Rentangan skor & $2-10$ & $6-20$ \\
St.Deviasi & 1,310 & 1,558 \\
Varians & 4,338 & 5,545 \\
\hline
\end{tabular}

Sumber: data diolah peneliti (2018)

\section{Analisis Data Hasil Uji Efektivitas}

Analisis statistik yang digunakan untuk melihat perbedaan hasil Pre test dan Post test Treatment pada kedua kelompok menggunakan $t$-test. Sebagai prasyarat $t$-test setiap data yang diperoleh dilakukan uji normalitas. Hasil analsis statistik diuraikan sebagai berikut.

\section{Uji Normalitas}

Uji normalitas dengan uji-Liliefors terhadap data skor pre test, post test, dan gain score pre tes-post test dari kelompok treatment dan control. Kriteria pengujian ditetapkan berdasarkan $\mathrm{L}_{\text {hitung }}$ yang diperoleh melalui Uji Liliefors terhadap data dari keempat kelompok yaitu sebagai berikut.

$\mathrm{L}_{\text {hitung }}<\mathrm{L}_{\text {tabel }}$ : Data berdistribusi normal

$\mathrm{L}_{\text {hitung }}>\mathrm{L}_{\text {tabel }}$ : Data tidak berdistribusi normal

Jika $\mathrm{L}_{\text {hitung }}<\mathrm{L}_{\text {tabel}}$, maka $\mathrm{H}_{0}$ diterima yang bermakna bahwa data skor pre test, post test, dan gain score dari seluruh sampel tersebut berdistribusi normal.

Hasil uji normalitas dapat dilihat pada tabel 2 di bawah ini. 
Jurnal Riset Manajemen Sains Indonesia (JRMSI) | Vol 9, No. 2, 2018

e-ISSN: 2301-8313

http://doi.org/10.21009/JRMSI

Tabel 2. Hasil Analisis Uji Normalitas Kelompok Treatment dan Control pada Data Skor Jawaban Pengetahuan tentang Pengelolaan Produk Olahan Cabai

\begin{tabular}{|c|c|c|c|c|c|}
\hline & & $\begin{array}{l}\text { Pret test } \\
\text { Treatment }\end{array}$ & $\begin{array}{c}\text { Post test } \\
\text { Treatment }\end{array}$ & Pret test Control & $\begin{array}{l}\text { Post test } \\
\text { Control }\end{array}$ \\
\hline $\mathrm{N}$ & & 40 & 40 & 40 & 40 \\
\hline \multirow{2}{*}{ Normal Parameters ${ }^{\mathrm{a}, \mathrm{b}}$} & Mean & 18.28 & 31.67 & 21.60 & 28.07 \\
\hline & Std. Deviation & 2.742 & 2.708 & 3.159 & 2.588 \\
\hline \multirow{2}{*}{ Most Extreme } & Absolute & .141 & .155 & .082 & .117 \\
\hline & Positive & .088 & .086 & .082 & .082 \\
\hline Differences & Negative & -.139 & -.153 & -.067 & -.115 \\
\hline Kolmogorov-Smirnov Z & & 1.103 & 1.215 & 649 & .922 \\
\hline Asymp. Sig. (2-tailed) & & .172 & .102 & .788 & .359 \\
\hline
\end{tabular}

a. Test distribution is Normal.

b. Calculated from data.

Sumber: data diolah peneliti (2018)

Berdasarkan tabel di atas terlihat bahwa Asymp. Sig. (2-tailed) lebih besar dari $\alpha=0,05$; sesuai dengan kriteria pengujian, maka $\mathrm{H}_{0}$, artinya data berdistribusi secara normal dan dapat dipergunakan untuk uji efektivitas.

\section{Uji Efektivitas}

Hasil analisis Uji Efektivitas dilakukan untuk membedakan rata-rata variabel kriterium dua kelompok. Untuk menguji hipotesis perbedaan parameter antara dua kelompok dapat digunakan statistik uji-t. Dengan persyaratan analisis uji tersebut harus terpenuhi, yaitu penempatan subjek dalam kelompok-kelompok yang diuji harus dipilih secara acak, datanya harus normal. Kriteria pengujian ditetapkan berdasarkan hasil perhitungan nilai statistik uji - dengan ketentuan sebagai berikut.

$\mathrm{H}_{0}$ : diterima jika $\left|\mathrm{t}_{\text {hitung }}\right|<\mathrm{t}_{\text {tabel }}$

$\mathrm{H}_{0}$ : ditolak jika $\left|\mathrm{t}_{\text {hitung }}\right|>\mathrm{t}_{\text {tabel }}$

Dengan taraf signifikansi $\mathrm{dk}(78) \mathrm{t}_{\text {tabel }} 5 \%=1,98$

Dengan taraf signifikansi $\mathrm{dk}(78) \mathrm{t}_{\text {tabel }} 1 \%=2,62$

1) Uji Efektivitas Independen pada Skor Post-Test Kelompok Control dan Kelompok Treatment Pelatihan Partisipatif Pengelolaan Produk Olahan Cabai (P4OC) 
Berdasarkan hasil analisis uji efektivitas independen (Independent sample t-test) pada skor post-test kelompok control dan kelompok treatment, diperoleh $\mathrm{t}_{\text {hitung }}=4,40>\mathrm{t}_{\text {tabel }}=1,98$ pada $\alpha=0,05$. Dengan demikian $\mathrm{H}_{0}$ ditolak yang berarti bahwa terdapat perbedaan yang nyata antara skor post-test pada kelompok control dan skor post-test pada kelompok treatment. Artinya pengetahuan tentang pengelolaan produk olahan cabai rumah tangga pada kelompok yang mengikuti Pelatihan Partisipatif Pengelolaan Produk Olahan Cabai (P4OC) 1, P4OC 2, P4OC 3, dan P4OC 4 (treatment) dan yang tidak mengikuti (control) menunjukkan perbedaan yang nyata.

2) Uji Efektivitas Dependen pada Skor Pre-Test dan Post-Test Kelompok Control Pelatihan Partisipatif Pengelolaan Produk Olahan Cabai

Berdasarkan hasil analisis uji uji efektivitas dependen (dependent sample t-test) pada skor pre-test dan post-test kelompok control, diperoleh $t_{\text {hitung }}=8,12$ $>\mathrm{t}_{\text {tabel }}=1,98$ pada $\alpha=0,05$. Dengan demikian $\mathrm{H}_{0}$ ditolak yang berarti bahwa terdapat perbedaan yang nyata antara skor pre-test dan post-test pada kelompok control. Artinya pengetahuan tentang pengelolaan produk olahan cabai pada kelompok yang mengikuti PPPOC 1, PPPOC 2, PPPOC 3, dan PPPOC 4 berdasarkan skor pre-test dan post-test control menunjukkan perbedaan yang nyata.

3) Uji Efektivitas Dependen pada Skor Pre-Test dan Post-Test Kelompok Treatment Pelatihan Partisipatif Pengelolaan Produk Olahan Cabai

Berdasarkan hasil analisis uji uji efektivitas dependen (dependent sample t-test) pada skor pre-test dan post-test kelompok treatment, diperoleh $\mathrm{t}_{\text {hitung }}=$ $18,68>\mathrm{t}_{\text {tabel }}=1,98$ pada $\alpha=0,05$. Dengan demikian $\mathrm{H}_{0}$ ditolak yang berarti bahwa terdapat perbedaan yang nyata antara skor pre-test dan post-test pada kelompok treatment. Artinya pengetahuan tentang pengelolaan produk olahan cabai pada kelompok yang mengikuti P4OC 1, P4OC 2, P4OC 3, dan P4OC 4 menunjukkan perbedaan yang nyata jika dibandingkan dengan sebelum mengikutinya. 
4) Uji Efektivitas Independen pada Gain Score Kelompok Control dan Kelompok Treatment Pelatihan Partisipatif Pengelolaan Produk Olahan Cabai

Berdasarkan hasil analisis uji efektivitas independen (Independent sample t-test) pada gain score antara kelompok control dan kelompok treatment, diperoleh $t_{\text {hitung }}=15,54>\mathrm{t}_{\text {tabel }}=1,98$ pada $\alpha=0,05$. Dengan demikian $\mathrm{H}_{0}$ ditolak yang berarti bahwa terdapat perbedaan yang nyata pada gain score antara kelompok control dengan kelompok treatment. Artinya pada kelompok ibu-ibu rumah tangga yang menggunakan P4OC 1, P4OC 2, P4OC 3, dan P4OC 4 menunjukkan peningkatan pengetahuan tentang pengelolaan produk olahan cabai rumah tangga yang lebih tinggi dibandingkan dengan kelompok ibu-ibu rumah tangga yang tidak mengikuti P4OC 1, P4OC 2, P4OC 3, dan P4OC 4. Secara rinci hasil uji beda dapat dilihat pada tabel 3 di bawah ini.

Tabel 3. Hasil Analisis Uji Efektivitas pada Kelompok Treatment dan Control Pelatihan Pengelolaan Produk Olahan Cabai Uji Statistik

\begin{tabular}{lccccc}
\multicolumn{1}{c}{ Kelompok Uji } & $\mathrm{dk}$ & $\mathrm{n}$ & $\mathrm{t}_{\text {hitung }}$ & $\mathrm{t}_{\text {tabel }}$ & $\mathrm{t}_{\text {tabel }(0.01)}$ \\
& & & & & \\
\hline Post test Treatment - Control & 78 & 80 & $4,40 * *$ & 1,98 & 2,62 \\
Pret test - Post test Control & 78 & 80 & $8,12^{* *}$ & 1,98 & 2,62 \\
Pretes - Postes Treatment & 78 & 80 & $18,68 * *$ & 1,98 & 2,62 \\
Gain Score & & & & & \\
Kelompok Treatment - Control & 78 & 80 & $14,54 * *$ & 1,98 & 2,62 \\
\hline$* * \mathrm{P}<0,01 ; * \mathrm{P}<0,05$ & & & &
\end{tabular}

Sumber: data diolah peneliti (2018)

Berdasarkan perhitungan di atas bahwa hasil uji t-test P4OC antara skor post test kelompok treatment dengan control (gain score) diperoleh $\mathrm{t}_{\text {hitung }}$ 14,54 $>\mathrm{t}_{\text {tabel }}$ 1,98. Dengan demikian $\mathrm{H}_{0}$ ditolak yang berarti terdapat perbedaan antara kelompok treatment dengan control. Artinya perbedaan yang sangat signifikan antara skor P4OC yang mengikuti dengan yang tidak mengikuti P4OC, dimana skor nilai post-pre test treatment sebesar 18,68 lebih tinggi daripada ibu-ibu 
rumah tangga yang tidak mengikuti $\mathrm{P} 4 \mathrm{OC}$ yaitu skor nilai post-pre test control sebesar 8,12 .

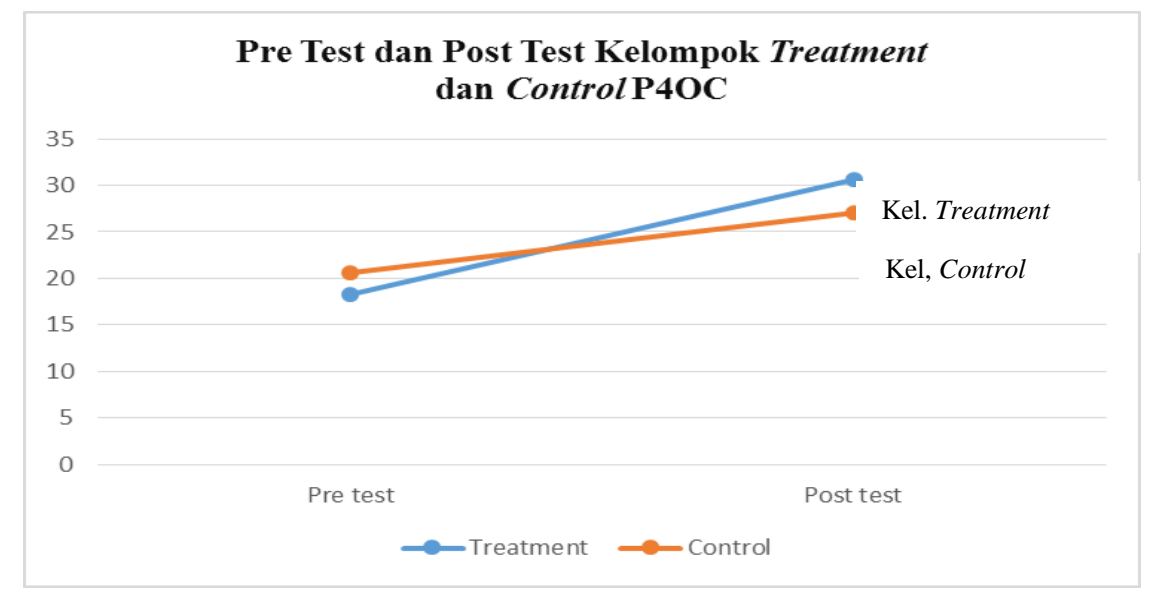

Gambar 4 Skor Pre test - Post test Kelompok Treatment dan Control Pada Uji Efektivitas P4OC

Sumber: data diolah peneliti (2018)

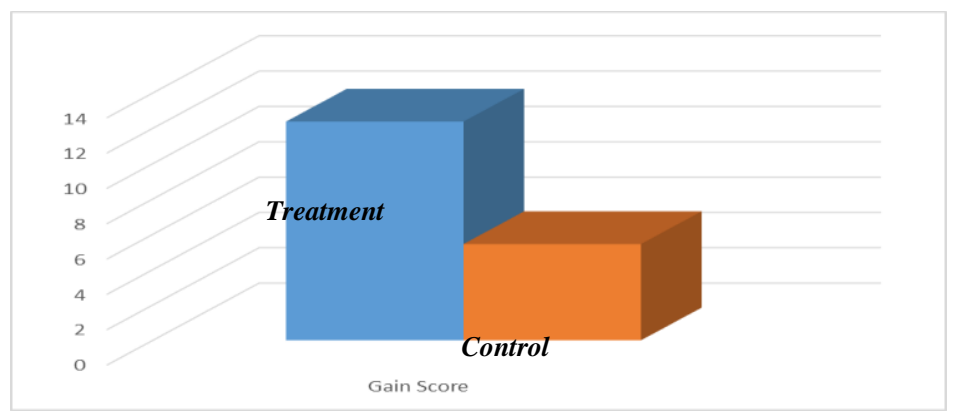

Gambar 5 Gain Score Pelatihan Partisipatif Pengelolaan Produk Olahan Cabai

Sumber: data diolah peneliti (2018)

Berdasarkan analisis data hasil uji efektivitas maka diperoleh hasil penelitian yang menjawab pertanyaan dalam rumusan masalah sebagai berikut.

1. Model pelatihan partisipatif dapat meningkatkan pengetahuan masyarakat dalam mengelola produk olahan cabai dan menjadi daya tarik bagi masyarakat di Desa Tangsi Jaya Kecamatan Gunung Halu - Bandung Barat.

2. Model pelatihan partisipatif efektif dalam meningkatkan pengetahuan masyarakat dalam mengelola produk olahan cabai. 
Jurnal Riset Manajemen Sains Indonesia (JRMSI) | Vol 9, No. 2, 2018

e-ISSN: 2301-8313

http://doi.org/10.21009/JRMSI

\section{KESIMPULAN DAN SARAN}

Pengembangan pelatihan dirancang berdasarkan desain model pelatihan partisipatif dan analisis material pada pengelolaan produk olahan cabai. Substansi materi dikembangkan disesuaikan dengan tingkat keterampilan ibu-ibu rumah tangga. Kondisi dan fenomena masyarakat pedesaan berfungsi sebagai sumber belajar.

Pelatihan partisipatif pengelolaan produk olahan cabai terdiri dari komponenkomponen yang menggambarkan kegiatan belajar dengan pendekatan pengetahuan tentang pengelolaan produk olahan cabai, yang dimulai dengan eksplorasi fenomena masyarakat pedesaan dan informasi tentang produk olahan cabai sehingga dapat meningkatkan peran ibu-ibu rumah tangga dalam menambah pendapatan keluarga.

Paket pelatihan model partisipatif yang dikembangkan memiliki efektivitas dalam meningkatkan pengetahuan tentang pengelolaan produk olahan cabai yang dapat menambah pendapatan keluarga.

\section{DAFTAR PUSTAKA}

Gilarso, T. (2002). Pengantar Ilmu Ekonomi Bagian Makro. Yogyakarta: Kanisius.

Hasibuan, Malayu S.P. (2005). Manajemen Sumber Daya Manusia, Edisi Revisi. Jakarta: Bumi Aksara,

Lipsey, Richard G. et. al. (2003). Pengantar Makroekonomi. Jakarta: Erlangga.

Mathis, Robert L. dan John H. Jackson. (2002). Manajemen Sumber Daya Manusia, Edisi Pertama. Jakarta: Salemba Empat.

Samadi, Budi. (2007). Budidaya Cabai Secara Komersial. Yogyakarta: Yayasan Pustaka Nusatam.

Sukmayani, Ratna, dkk. (2008). Ilmu Pengetahuan Sosial. Jakarta: PT Galaxy Puspa Mega.

Sulistiyani, Ambar, Teguh dan Rosidah. (2003). Manajemen Sumber Daya Manusia. Yogyakarta: Graha Ilmu.

Suprijanto. (2005). Pendidikan Orang Dewasa: Dari Teori Hingga Aplikasi. Jakarta: PT Bumi Aksara. 